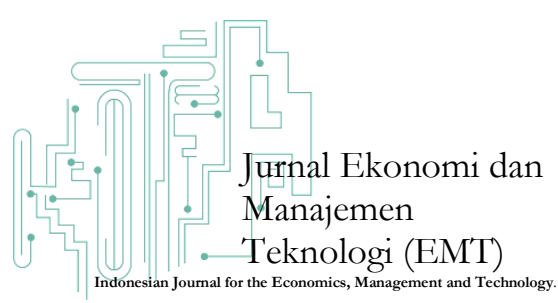

\title{
Pengaruh Belanja Ekonomi di Era Desentralisasi Fiskal terhadap Kemiskinan di Indonesia
}

\author{
Zainuddin ${ }^{1}$, Hamdani ${ }^{2}$, Ilyas ${ }^{3}$, Maryam ${ }^{4}$ \\ 1,3,4 Fakultas Ekonomi, Universitas Serambi Mekkah, Kota Banda Aceh, Indonesia. \\ ${ }^{2}$ Fakultas Ekonomi, Politeknik Kutaraja, Kota Banda Aceh, Indonesia
}

\begin{abstract}
Abstrak. Tujuan penelitian ini adalah untuk mengetahui pengaruh pengeluaran sektoral pemerintah provinsi terhadap kemiskinan di era desentralisasi fiskal di Indonesia. Sedangkan variabel pengeluaran sektoral yang dianggap berkaitan erat dengan kemiskinan adalab belanja ekonomi, belanja perumahan dan fasilitas umum, belanja kesehatan, belanja pendidikan, dan belanja perlindungan sosial menurut provinsi di Indonesia. Data dalam penelitian ini adalah data panel yaitu cross section 33 provinsi, dan time series 4 tabun yaitu periode 2012 - 2015. Setelah dilakukan uji Chow dan uji Hausman, serta uji pengali LaGrange dilakukan analisis Model dalam penelitian ini ditetapkan menjadi model random effect, yang merupakan model analisis umum dalam analisis data panel. Penelitian ini menyimpulkan bahwa pengeluaran ekonomi terbadap kemiskinan sebagian negatif, artinya pengeluaran sektor tersebut dapat mengurangi kemiskinan pada era desentralisasi fiskal di Indonesia. Dalam analisis ini diketabui bahwa kemampuan variabel independen dalam menjelaskan variabel dependen sebesar 0.190165 unit atau 19,02\%, dan sisanya 80,98\% dijelaskan oleh variabel lain yang tidak termasuk dalam penelitian ini.
\end{abstract}

Kata kunci: Kemiskinan; Pengeluaran Ekonomi; Desentralisasi; Fiskal.

\begin{abstract}
The purpose of this study was to determine the effect of provincial government sectoral spending on poverty in the era of fiscal decentralization in Indonesia. Meanwhile, the sectoral expenditure variables that are considered closely related to poverty are economic spending, housing and public facilities spending, health spending, education spending, and social protection spending according to provinces in Indonesia. The data in this study is panel data, namely cross-section of 33 provinces, and time series of 4 years, namely the period $2012-2015$. After the Chow test and Hausman test, as well as the lagrange multiplier test, the analysis model in this study was determined to be the random effect model, which is a common analysis model in panel data analysis. This study concludes that partially negative economic spending on poverty, meaning that sector spending can reduce poverty in the era of fiscal decentralization in Indonesia. In this analysis, it was found that the ability of the independent variable in explaining the dependent variable was 0.190165 units or $19.02 \%$, and the remaining $80.98 \%$ was explained by other variables not included in this study.
\end{abstract}

Keywords: Poverty; Economic Spending; Decentralization; Fiscal. 


\section{Pendahuluan}

Kemiskinan adalah suatu situasi dimana seseorang atau rumah tangga mengalami kesulitan untuk memenuhi kebutuhan dasar, sementara lingkungan pendukungnya kurang memberikan peluang untuk meningkatkan kesejahteraan secara berkesinambungan atau untuk keluar dari kerentanan (Chayat et al, 2007:2). Secara global atau internasional bahwa kemiskinan dipandang sebagai keadaan yang harus di berantas, seperti upaya yang dilakukan dengan deklarasi milenium oleh Perserikatan Bangsa-Bangsa pada bulan September 2000 tentang Pembangunan Milenium (Millennium Development Goals / MDGs), dan yang tergolong miskin adalah yang berpenghasilan $\$ 1.25$ per hari (Omari and Mutari 2016).

Diantara faktor penyebab kemiskinan adalah tidak memiliki tanah dan modal, terbatasnya ketersediaan bahan kebutuhan dasar, sarana dan prasarana, kebijakan pembangunan yang bias di perkotaan dan bias sektor, adanya perbedaan kesempatan diantara anggota masyarakat dan sistem yang kurang mendukung, adanya perbedaan sumber daya manusia dan perbedaan antar sekor ekonomi, rendahnya pembentukan modal didalam masyarakat, tidak adanya tata bagian dari integral dari pembangunan nasional dilaksanakan melalui otonomi daerah yang mulai dilaksanakan pada tahun 2001. Dengan diberlakukannya undang-undang tersebut, maka terjadi perubahan sistem pemerintahan di Indonesia yang sentralistik ke sistem otonomi daerah atau disebut juga dengan desentralisasi fiskal. Dalam perjalanannya terjadi perubahan atau revisi undang-undang otonomi dengan lahirnya Undang-Undang Nomor 32 tahun 2004 tentang pemerintah daerah dan Undang-Undang Nomor 33 tentang perimbangan keuangan pusat dan daerah.

Pelaksanaan desentralisasi fiskal merupakan suatu respon pemerintah terhadap tata kelola pemerintahan antara pusat dan daerah (subnasional) untuk memberikan keleluasan kepada pemerintah daerah dalam melakukan penetapan pembelanjaan pembangunannya. Seperti untuk memenuhi kebutuhan penduduk lokal, dan alokasi sumber daya menjadi lebih efisien (Jia, Guo, and Zhang 2014). Namun, setelah 15 tahun pelaksanaan otonomi daerah atau desentralisasi fiskal diberlakukan terlihat angka masih tinggi, dan untuk lebih jelas setelah 15 tahun pelaksanaan atonomi daerah atau sudah berada pada era desentralisasi angka kemiskinan, seperti pada gambar berikut ini:

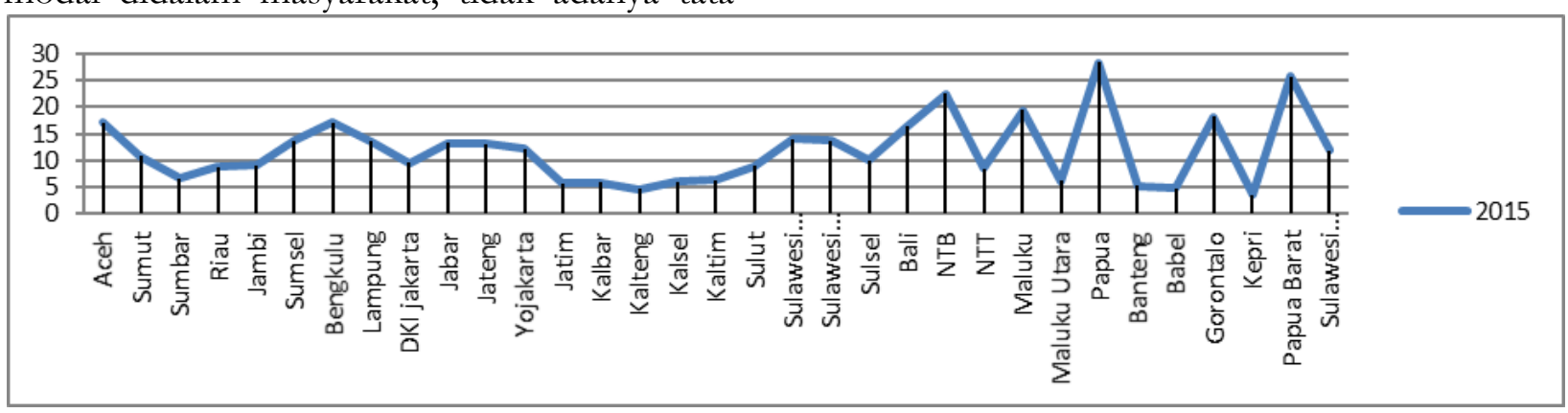

Gambar 1. Persentase MIS terhadap total penduduk menurut provinsi tahun 2015 (sumber; bps.go.id)

kelola pemerintah yang bersih dan baik (World Bank, 2006). Mengenai faktor tata kelola pemerintahan yang tidak baik, pemerintah Indonesia melakukan suatu reformasi birokrasi yaitu diterapkannya suatu kebijakan otonomi daerah atau desentralisasi fiskal.

Undang-Undang Nomor 22 Tahun 1999 yang mengamanatkan bahwa daerah diberi keleluasaan untuk menyelenggarakan otonomi daerah dan Undang-Undang Nomor 25 Tahun 1999 bahwa pembangunan daerah sebagai
Pada masa otonomi daerah atau era desentralisasi fiskal, pemerintah otonom memiliki kebebesaan dalam menentukan anggaran belanja untuk mencapai tujuan dalam rangka peningkatan kesejahteraan masyarakat. Akan tetapi tujuan tersebut belum maksimal dapat dicapai, walaupun anggaran belanja pembangunannya setiap tahun ada peningkatan. Pelaksanaan otonomi daerah atau desentraslisasi fiskal yang dituangkan pada kewenanangan pemerintah daerah (subnasional) sebenarnya dapat menurunkan kemiskinan. Belanja ekonomi 
dapat menurunkan tingkat kemiskinan (Ababa, 2009). Kemudian, Era desentralisasi juga dapat menciptakan keadaan yang efisien pada tingkat pemerintah daerah, seperti yang dinyatakan oleh Yushkov (2015) bahwa efisiensi produktif juga bisa lebih tinggi pada era desentralisasi fiskal karena pemerintah subnasional memiliki pengetahuan yang lebih baik tentang kebutuhan warga dan pengalaman dalam pengadaan barang publik, sehingga dapat menghasilkan barangbarang dengan biaya rendah.

Berdasarkan uraian sebelumnya, maka dapat dinyatakan bahwa kemiskinan secara rata-rata pada tahun 2015 untuk seluruh provinsi adalah sebesar $11.88 \%$, dan tingkat rata-rata kemiskinan tersebut terasa masih tinggi yang menyebar diseluruh provinsi di Indonesia, walaupun pemerintah sudah memberlakukan otonomi daerah yang luas atau sudah berada pada era desentralisasi fiskal selama 15 tahun. Sedangkan, belanja pemerintah provinsi selama periode 2010-2015 terlihat banyak meningkat, namun ada juga yang menurun.

Pelaksanaan otonomi daerah atau desentralisasi fiskal sudah mencapai 15 tahun lamanya, namun masih terlihat angka kemiskinan di setiap provinsi di Indonesia masih berada diatas $10 \%$ atau tepatnya sebesar $11.88 \%$. Padahal pada era desentralisasi fiskal pemerintah otonomi memiliki keleluasaan dalam merencanakan dan menetapakan anggaran belanjanya untuk pelaksanaan pembangunan yang dapat memberi dampak pada peningkatan tingkat kesejahteraan masyarakat dan dengan terjadinya peningkatakan tingkat kesejahteraan, maka akan dapat menurunkan angka kemiskinan. Berdasarkan uraian latar belakang masalah dan rumusan masalah sebelumnya, maka dapat diformulasikan pertanyaan penelitian ini adalah "Apakah belanja ekonomi berpengaruh terhadap kemiskinan pada era desentralisasi fiskal di Indonesia".

\section{Literature Review}

\section{Kemiskinan}

Menurut Jhingan (2013:33-34) dan Todaro \& Smith (2006:66-67) kemiskinan sinonim dengan keterbelakangan, maka sebuah negara dikatakan miskin akan terbelakang karena tidak memiliki sumber yang diperlukan untuk meningkatkan pembangunan, dan tinggi rendahnya tingkat kemiskinan tergantung pada tingkat pendapatan nasional rata-rata dan lebar sempitnya kesenjangan distribusi pendapatan. Tidak ada konsensus umum dalam mendefinisikan kemiskinan, namun di masa lalu, kemiskinan terutama dipandang sebagai masalah inefisiensi ekonomi, tetapi maknanya kini telah diperluas untuk mencakup kekurangan materi, kekurangan sumber daya manusia, termasuk rendah prestasi di bidang pendidikan dan kesehatan, ketidakberdayaan dan risiko kelaparan (Vijayakumar \& Olga 2012). kemiskinan adalah dipersepsikan sebagai kelangkaan keuangan dan material, serta sangat menentukan tingkat kesehatan (Bratanova et al. 2016 dan Reid et al, 2016). Seperti contoh ketidak mempauan menyediakan bahan bakar untuk penghangatan di rumah merupakan satu bentuk kemiskinan (Mavrogianni et al, 2017).

Banyak faktor penyebab terjadinya kemiskinan, diantaranya karena kehilangan pekerjaan dan rendahnya pendapatan atau berpenghasilan rendah untuk memenuhi kebutuhannya (Reid et al. 2016; Mai \& Mahadevan 2016; dan Moore \& Donaldson, 2016). Selanjutnya, kemiskinan bukan hanya karena disebabkan oleh kekurangan materi saja, akan tetapi banyak disebabkan oleh rendahnya pelayanan dan tingkat pendidikan, kesehatan, dan perumahan atau dengan kata lain disebabkan karena ketidakmampuan memenuhi kebutuhan fisik manusia (Boyle \& Boyle 2015; dan Vijayakumar \& Olga 2012). Berdasarkan uraian sebelumnya, maka dapat dinyatakan bahwa kemiskinan terjadi disebabkan oleh banyak faktor, diantaranya adalah rendahnya pendapatan, rendahnya tingkat pendidikan, tingkat pertumbuhan penduduk yang tinggi yang tidak sebanding dengan ketersediaan lapangan pekerjaan, fasilitas pelayanan kesehatan yang relatif buruk, dan tingginya ketimpangan distribusi pendapatan.

Ada dua kelompok kemiskinan, yaitu absolute poverty dan relative poverty. Absolute poverty adalah sejumlah penduduk yang tidak mampu mendapatkan sumber daya yang cukup untuk memenuhi kebutuhan dasar (Todoro \& Smith 2006:242-243; Vijayakumar \& Olga 2012; Boyle \& Boyle 2015; dan Bratanova et al. 2016). 
Sedangkan, relative poverty adalah sejumlah penduduk memiliki sumber daya yang mampu untuk memenuhi kebutuhannya, namun ada yang kurang dibandingkan dengan yang lain (Boyle \& Boyle 2015; dan Bratanova et al. 2016).

Penduduk miskin adalah penduduk yang memiliki rata-rata pengeluaran perkapita perbulan dibawah garis kemiskinan. Garis kemiskinan yang dimaksud adalah 1) Garis Kemiskinan (GK) merupakan penjumlahan dari Garis Kemiskinan Makanan (GKM) dan Garis Kemiskinan Non Makanan (GKNM). Penduduk yang memiliki rata-rata pengeluaran perkapita per bulan dibawah Garis Kemiskinan dikategorikan sebagai penduduk miskin, 2) Garis Kemiskinan Makanan (GKM) merupakan nilai pengeluaran kebutuhan minimum makanan yang disetarakan dengan 2100 kilokalori perkapita perhari. Paket komoditi kebutuhan dasar makanan diwakili oleh 52 jenis komoditi (padi-padian, umbiumbian, ikan, daging, telur dan susu, sayuran, kacang-kacangan, buah-buahan, minyak dan lemak, dll), dan 3) Garis Kemiskinan Non Makanan (GKNM) adalah kebutuhan minimum untuk perumahan, sandang, pendidikan dan kesehatan. Paket komoditi kebutuhan dasar non makanan diwakili oleh 51 jenis komoditi di perkotaan dan 47 jenis komoditi di pedesaan. Garis kemiskinan dapat dihitung dengan formula sebagai berikut:

$$
\mathrm{GK}=\mathrm{GKM}+\mathrm{GKNM}
$$

Notasi:

$$
\begin{array}{ll}
\text { GK } & =\text { Garis Kemiskinan } \\
\text { GKM } & =\text { Garis Kemiskinan Makanan }
\end{array}
$$$$
\text { GKNM }=\text { Garis Kemiskinan Non Makanan }
$$

\section{Selanjutnya (Mai \& Mahadevan 2016)} kemiskinan dapat diukur dengan indeks kemiskinan, yaitu dilakukan dengan formula sebagai berikut:

$$
P_{\alpha, t}=\frac{1}{n} \sum_{i=1}^{q}\left(\frac{Z_{t}-Y_{i t}}{Z_{t}}\right)^{\alpha}
$$

Notasi :

$P_{\alpha, t}:$ Indeks kemiskinan

$Z_{t}$ : Garis kemiskinan dalam gelombang $t$

$Y_{i t}$ : Pengeluaran orang miskin $i(i=1 \ldots$ q)

$\alpha$ : Parameter aversion kemiskinan yang mendefinisikan jenis ukuran kemiskinan.
Kemudian untuk pengukuran total kemiskinan selama pengamatan/gelombang $(t=1 . . \mathrm{T})$ dapat dilakukan dengan formula sebagai berikut:

$$
P_{\alpha}^{T o t a l}=\frac{1}{T} \sum_{t=1}^{T} P_{\alpha, t}
$$

\section{Era Desentralisasi Fiskal}

Kebijakan desentralisasi fiskal akan dapat menciptakan efisiensi ditingkat subnasional atau provinsi, karena pemerintah dibawahnya atau pemerintah di tingkat subnasional lebih memahami tentang kebutuhannya dan lebih berpengalaman dalam pengadaan barang-barang publik dengan cost yang rendah (Martinezvazquez \& Mcnab 2003; dan Yushkov 2015). Sejalan dengan pendapat Neyapti (2010) bahwa dengan desentralisasi fiskal akan lebih efisien dalam pengeluaran karena pemerintah lokal lebih memahami preferensi lokal. Tujuan utama dari desentralisasi fiskal adalah untuk memberikan kemudahan kepada pemerintah lokal dalam membangun infrastruktur sosial (barang publik), dimana fungsi utamanya agar tidak melebar kesenjangan spasial dalam pembangunan infrastruktur sosial (Kalirajan, 2012).

Selanjutnya, desentralisasi fiskal adalah mengalihkan tanggung jawab pengeluaran pemerintah pusat kepada pemerintah lokal atau subnasional, seperti untuk memenuhi kebutuhan penduduk lokal, dan alokasi sumber daya menjadi lebih efisien (Jia et al. 2014), dan kewenangan pemerintah daerah dalam mengambil keputusan memproduksi barang publik dan pelayanan untuk peningkatan kesejahteraan masyarakat lokal (Kumari, 2016). Desentralisasi fiskal juga bisa dinyatakan sebagai sarana mempromosikan pertumbuhan ekonomi jangka panjang bagi daerah lokal, berdasarkan pandangan bahwa dengan desentralisasi fiskal akan terjadi alokasi sumber daya yang lebih baik dan lebih produktif karena wilayahnya yang kecil (Xie \& Davoodi 1999; dan Thornton \& Thornton 2007).

\section{Belanja Sektoral Pada Era Desentralisasi Fiskal}

Desentralisasi fiskal bisa dilihat sebagai total pengeluaran pemerintah provinsi di Indonesia. Pernyataan ini sejalan dengan pendapat Jin \& Zou (2005) dan Jia et al. (2014) bahwa desentralisasi fiskal dapat dilihat dari total belanja 
pemerintah lokal atau daerah. Desenntralisasi fiskal juga diukur sebagai kemampuan dalam mengatur pengumpulan pajak, dan pengeluaran atau belanja pemerintah daerah (Noor 2012:38). Dan belanja ekonomi dapat menurunkan kemiskinan, seperti yang dinyatakan (Sanchez 2008) bahwa kebijakan belanja ekonomi bidang transportasi memberi efek pada kemiskinan. Pengembangan proyek pertanian dapat meningkatkan pendapatan perempuan dan menurukan kemiskinan (Johnson et al 2016). Pengukuran belanja ekonomi dapat dilakukan dengan formula sebagai berikut:

Belanja Ekonomi = Total belan ja ekonomi per tahun menurut provinsi Total penduduk menurut provinsi

Berdasarkan uraian sebelumnya, maka dapat digambarkan skema penelitian ini adalah sebagai berikut:

\begin{tabular}{|c|c|c|}
$\begin{array}{c}\text { Belanja Ekonomi } \\
\text { (BEK) }\end{array}$ & $\begin{array}{c}\text { Belanja Ekonomi } \\
\text { (BEK) }\end{array}$ \\
\cline { 2 - 3 }
\end{tabular}

Gambar 2. Skematis Kerangka Pemikiran.

Berdasarkan gambar skematis kerangka pemikiran diatas, maka dapat dihipotesiskan adalah belanja ekonomi berpengaruh terhadap kemiskinan pada era desentralisasi fiskal di Indonesia.

\section{Metodologi Penelitian}

\section{Data dan Sumber Data}

Data yang digunakan dalam penelitian ini adalah data sekunder yang bersumber dari publikasi resmi, yaitu dari publikasi Badan Pusat Statistik, dan publikasi Direktorat Jendral Perimbangan Keuangan, serta sumber-sumber lain yang dipublikasikan. Penelitian ini dilakukan terhadap data dari periode tahun 2012 sampai dengan 2015. Data diperoleh melalui www.bps.go.id, dan www.djpk.go.id.

\section{Model Analisis data}

Penelitian ini mempergunakan data deret waktu (time series) dan kerat lintang (cross section) yang menghasilkan data yang bersifast data panel. Berdasarkan skema kerangka pemikiran, maka dapat diformulakan persamaan dasar dalam penelitian ini adalah:

\section{$M I S=f(B E K)$}

Menurut Green (2012:349) dan (Feng et al. 2017) bahwa secara umum regresi data panel adalah sebagai berikut:

$$
\begin{aligned}
& Y_{i t}=\alpha+X_{i t}^{\prime} \beta+\varepsilon_{i t} \\
& \text { dimana, } i=1, \ldots, \mathrm{n}, \text { dan } t=1, \ldots, \mathrm{T}
\end{aligned}
$$

Berdasarkan persamaan dasar penelitian ini, maka dapat diformulasikan persamaanya adalah sebagai berikut:

$$
\underset{\varepsilon_{i t}}{\log \left(M I S_{i t}\right)}=\beta_{0}+\beta_{1} \log \left(B E K_{i t}\right)+
$$

Dimana, $M I S_{t i}$ adalah Jumlah Penduduk miskin, $B E K_{i t}$ adalah Belanja ekonomi perkapita, $I$ adalah Cross section $(i=1, \ldots, \mathrm{N}), t$ adalah Time series $(t=1, \ldots, \mathrm{T}), \beta_{0}$ adalah Konstanta, $\beta_{1}$ adalah Koefisien atau parameter yang ditaksir, dan $\varepsilon_{i t}$ adalah Error.

Regresi data panel merupakan sekumpulan teknik untuk memodelkan pengaruh peubah penjelas terhadap peubah respon pada data panel. Secara umum ada dua pendekatan yang digunakan dalam menduga model dari data panel, yaitu model tanpa pengaruh individu (common effect) dan model dengan pengaruh individu (fixed effect dan random effect). Disamping itu, dalam analisis bisa juga dipergunakan persamaan kointegrasi (cointegration test) untuk jangka panjang dan Error Correction Model (ECM) untuk jangka pendek.

\section{Pemilihan Model Estimasi}

Untuk memilih salah satu model pada regersi data panel, yaitu pemilihan antara model efek tetap (fixed effect model) dengan model koefisien tetap (common effect model) bisa dilakukan dengn uji Chow. Jika nilai probabilitas cross-section $F$ lebih kecil dari nilai kritis (prob.cross-section $\mathrm{F}<0.05$ ), maka fixed effect model lebih baik dari pada common effect model. Jika prob.cross-section $\mathrm{F}>0.05$, maka common effect model lebih baik digunakan. Uji Hausman dilakukan untuk memilih model yang baik digunakan antara fixed effect model dan random effect model. Jika nilai probabilitas cross-section random lebih besar dari nilai kritis (prob.cross-section random $>0.05$ ), maka 
random effect model lebih baika dari pada fixed effect model. Jika prob.cross-section random < 0.05, maka fixed effect model lebih baik digunakan dibandingkan dengan random effect model. Uji Lagrange Multiplier dilakukan apabila hasil uji Chow dan uji Hausman tidak memiliki hasil yang konsisten. Dimana, dalam uji Lagrange Multiplier untuk memilih antara common effect model dan random effect model. Apabila nilai probabilitas Both-Breusch pagan lebih kecil dari nilai kritis, maka model yang terpelih adalah random effect model, dan sebaliknya apabila nilai probabilitas BothBreusch pagan lebih besar dari nilai kritis, maka model yang terpilih adalah common effect model.

\section{Hasil dan Pembahasan}

Selama periode pengamatan dari tahun 2012 sampai 2015 penyebaran kemiskinan (MIS) di setiap provinsi, seperti pada gambar berikut ini:

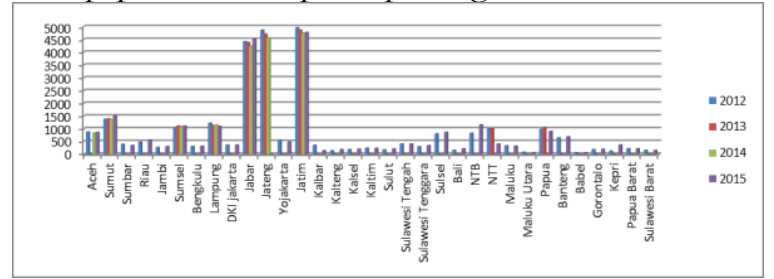

Gambar 3. Jumlah MIS menurut provinsi 2012-2105 (dalam ribuan)

Berdasarkan Gambar 3, terlihat bahwa jumlah penduduk miskin tertinggi masih terkonsentrasi di tiga provinsi yang ada di pulau jawa, yaitu provinsi Jawa Timur, Jawa Tengah, dan Jawa Barat. Jumlah penduduk miskin pada tiga provinsi tersebut pada tahun 2015, yaitu provinsi Jawa Timur adalah sebesar 4.775.970 jiwa, provinsi Jawa tengah adalah sebesar 4.505.780 jiwa, dan provinsi Jawa Barat adalah sebesar 4.505 .780 jiwa. Selanjutnya tiga provinsi yang jumlah penduduk miskin terendah pada tahun 2015, yaitu provinsi Bangka Belitung adalah sebesar 66.620 jiwa, provinsi Maluku Utara adalah sebesar 72.650 jiwa, dan provinsi Kalimantan Barat adalah sebesar 148.130 jiwa. Dengan demikian, jumlah penduduk miskin masih sangat tinggi berada di pulau jawa, hal ini disebabkan jumlah penduduk yang mendiami provinsi-provinsi di pulau jawa sangat tinggi dan padat.
Kemudian, perkembangan belanja ekonomi perkapita (BEK) yang dilaksanakan oleh provinsi-provnisi di Indonesia periode 20122015, seperti pada gambar berikut ini:

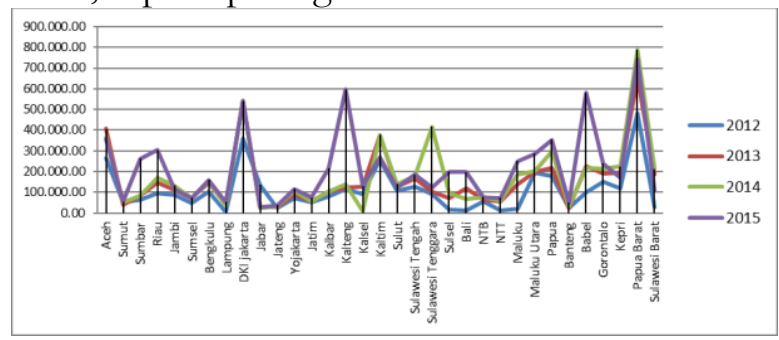

Gambar 4. BEK perkapita menurut provinsi $2012-2105$

Berdasarkan gambar diata, terlihat bahwa hampir seluruh provinsi terjadi perubahan pada belanja ekonomi perkapita adanya fluktuasi antar tahun ke tahun, seperti pada provinsi Aceh terjadi peningkatan dari tahun 2012 ke 2103, namun terjadi penurunan pada tahun 2014 hingga tahun 2015. Ada juga provinsi yang memiliki tren peningkatan dari tahun ke tahun seperti provinsi Jawa Timur. Dengan demikian, dapat dinyatakan penetapan belanja ekonomi masing-masing provinsi lebih banyak mengalami peningkatan dari tahun ke tahun.

\section{Deskripsi Variabel}

Tabel 1. Diekripsi Variabel

\begin{tabular}{lrr}
\hline & \multicolumn{1}{l}{ MIS } & \multicolumn{1}{l}{ BEK } \\
\hline Maximum & 4960500 & 788368.6 \\
Minimum & 66620.00 & 6730.190 \\
Std. Dev. & 1247239. & 153763.4 \\
Observation & 132 & 132 \\
\hline
\end{tabular}

Berdasarkan Tabel 1, dapat dijelaskan bahwa jumlah penduduk miskin (MIS) yang maksimum atau terbanyak adalah sebesar 4.960.500 jiwa berada pada provinsi Jawa Timur tahun 2012, dan yang memiliki jumlah penduduk miskin minimum atau terendah berada pada provinsi Bangka Belitung tahun 2015 sebanyak 66.620 jiwa. Sedangkan, nilai standar deviasi sebesar 1.247.239 adalah menandakan variabilitas atau sebaran data dari kemiskinan selama periode pengamatan sebesar 1.247.239 satuan. Selanjutnya, belanja ekonomi perkapita (BEK) tertinggi atau maksimum adalah sebesar Rp788,366.6 pada provinsi Papua Barat tahun 2014, dan BEK terendah sebesar Rp6.730.19 pada provinsi Lampung tahun 2012. Selanjutnya nilai standar deviasi sebesar 153.763,4 adalah 
menandakan variabilitas atau sebaran data BEK selama periode pengamatan sebesar 153.763,4 satuan.

\section{Uji hipotesis dan Uji Signifikansi}

Pengujian signifikansi dalam analisis ini dilakukan didasarkan atas hasil estimasi random effect model seperti terlampir (lampiran 13), dan hasil pengujiannya signifikansi seperti pada tabel berikut ini:

Tabel 2. Hasil Uji Hipotesis dan Signifikansi

\begin{tabular}{|c|c|c|c|}
\hline Variabel & Koefisien & Prob. & Signifikan \\
\hline $\mathrm{C}$ & 17.44302 & 0.0000 & \\
\hline BEK & -0.258035 & 0.0438 & $\mathrm{~S}$ \\
\hline \multicolumn{2}{|l|}{$R$ squared } & \multicolumn{2}{|l|}{0.190165} \\
\hline \multicolumn{2}{|c|}{ Durbin-Waston Stat } & \multicolumn{2}{|l|}{1.711018} \\
\hline
\end{tabular}

Berdasakan gambar tabel 2, dapat disimpulkan bahwa belanja ekonomi (BEK) berpengaruh terhadap kemiskinan pada era desentralisasi fiskal di Indonesia

\section{Pembahasan}

Berdasarkan hasil penelitian dan pengujian hipotesis dan uji signifikansi sebelumnya terdapat nilai konstanta sebesar 17,44362. Nilai ini menandakan apabila variabel belanja ekonomi, belanja perumahan dan fasilitas umum, belanja kesehatan, belanja pendidikan, dan belanja perlindungan sosial tidak ada, maka akan mengakibatkan kemiskinan sebesar 17,44362 satuan atau $17,44 \%$. Selanjutnya belanja ekonomi berpengaruh negative dan signifikan terhadap kemiskinan sebesar 0,258035, dan pengaruh ini dapat diartikan bahwa apabila terjadi satu satuan belanja ekonomi, maka akan mengakibatkan kemiskinan turun sebesar 25,80\%. Terjadi penurunan kemiskinan karena diadakan belanja ekonomi sudah sepatunya terjadi karena pada pos-pos yang ada didalam kelompok belanja ini adalah sangat berkenaan dengan aktivitas ekonomi masyarakat, seperti belanja ketenagakerjaan, koperasi dan usaha kecil menengah, pemberdayaan masyarakat dan desa, pertanian, kelautan dan perikanan, dan ketahanan pangan, ketransmigrasian, dan lain lain.

Hasil penelitian ini juga sesuai dengan hasil penelitian yang dilakukan oleh Enyim (2013) yang menyimpulkan bahwa belanja bantuan pertanian dapat mengurangi kemiskinan di Negeria. Omari and Mutari (2016) menyimpulkan hasil penelitiaanny adalah bahwa belanja pertanian dapat mengurangi kemiskinan di Kenya. Selanjutnya penelitian oleh Martens (2017) yang menyimpulkan bahwa belanja investasi yang berorientasi ekspor dapat mengurangi kemiskinan di Sinegal.

Nilai R squared sebesar 0,190165, nilai ini dapat dimaknai bahwa kemampuan dari variabel belanja ekonomi perkapita, belanja perumahan dan fasilitas umum perkapita, belanja kesehatan perkapita, belanja pendidikan perkapita, dan belanja perlindungan sosial perkapita dapat menjelaskan variabel kemiskinan sebesar 0,190165 satuan atau 19,02\%. Dan selebihnya atau sisanya sebesar 80,98\% dijelaskan oleh variabel lain yang tidak dimasukan dalam penelitian ini. Banyaknya variabel lain untuk menjelaskan kemiskinan menandakan bahwa kemiskinan merupakan suatu variabel yang sangat kompleks dan dipengaruhi oleh berbagai variable.

\section{Kesimpulan}

Upaya pemerintah Indonesia dalam program pengentasan kemiskinan dilakukan berbagai cara, salah satunya diterapkan desensentralisasi fiskal mulai tahun 2001 hingga saat sekarang. Dimana, pada era desentralisasi fiskal diberikan tanggung jawab lebih luas kepada pemerintah otonom, terutama pada sisi pengeluaran atau penetapan belanja. Belanja-belanja yang ditetapkan pemerintah daerah hendaknya akan dapat mempengaruhi penurunan kemiskinan. Berdasarkan hasil penelitian dan pembahasan sebelumnya, maka dapat disimpulkan bahwa Belanja ekonomi, belanja perumahan dan fasilitas umum, belanja kesehatan, belanja pendidikan, dan belanja sosial secara bersamasama berpengaruh terhadap kemiskinan pada era desentralisasi fiskal di Indonesia. Nilai $\mathrm{R}^{\wedge} 2$ sebesar 0,190165 dapat diartikan kemampuan dari belanja ekonomi, belanja perumahan dan fasilitas umum, belanja kesehatan, belanja pendidikan, dan belanja perlindungan sosial dalam menjelaskan kemiskinan sebesar 19.02\%, dan selebihnya sebesar $80.98 \%$ dijelaskan oleh variabel lain yang tidak dimasukan dalm penelitian ini. Banyaknya variabel yang lain untuk 
menjelaskan kemiskinan disebabkan karena variabel kemiskinan sangat luas dan dijelaskan oleh berbagai variabel.

\section{Daftar Pustaka}

Ade, Cahyat., Christian, G., \& Michaela, H. (2007). Mengkaji Kemiskinan dan Kesejahteraan Keluarga. Bogor: Cifor. Aksara.

Bratanova, B., Loughnan, S., Klein, O., Claassen, A., \& Wood, R. (2016). Poverty, inequality, and increased consumption of high calorie food: Experimental evidence for a causal link. Appetite, 100, 162-171.

Dercon, S., Gilligan, D. O., Hoddinott, J., \& Woldehanna, T. (2009). The impact of agricultural extension and roads on poverty and consumption growth in fifteen Ethiopian villages. American Journal of Agricultural Economics, 91(4), 1007-1021.

Greene, W. (2012). H.(2012): Econometric Analysis.

Indonesia, R. (1999). Undang-Undang Republik Indonesia Nomor 25 Tahun 1999 Tentang Perimbangan Keuangan antara Pemerintah Pusat dan Daerah. Jakarta (ID): RI.

Indonesia, R. (2004). Undang-Undang Republik Indonesia Nomor 22 Tahun 1999 Tentang Pemerintahan Daerah. Jakarta (ID): RI.

Indonesia, R. (33). Tahun 2004 tentang Perimbangan Keuangan antara Pemerintah Pusat dan Pemerintah Daerah. Direktorat Jenderal Otonomi Daerah, Jakarta.

Jhingan, M. L. (2016). Ekonomi pembangunan dan perencanaan. Jakarta: Rajawali Pers.

Jia, J., Guo, Q., \& Zhang, J. (2014). Fiscal decentralization and local expenditure policy in China. China Economic Review, 28, 107-122.
Jin, J., \& Zou, H. F. (2005). Fiscal decentralization, revenue and expenditure assignments, and growth in China. Journal of Asian Economics, 16(6), 1047-1064.

Johnson, N. L., Kovarik, C., Meinzen-Dick, R., Njuki, J., \& Quisumbing, A. (2016). Gender, assets, and agricultural development: Lessons from eight projects. World Development, 83, 295-311.

Kumari, R. (2016). Impact of Fiscal Decentralization on Policy of Local Goverment. International Journal of Advanced Research, 1013-1014.

Mai, T., \& Mahadevan, R. (2016). A research note on the poverty dynamics and cost of poverty inequality: Case study of Indonesia. Economic Analysis and Policy, 49, 100-107.

Martinez-Vazquez, J., \& McNab, R. M. (2003). Fiscal decentralization and economic growth. World development, 31(9), 15971616.

Neyapti, B. (2010). Fiscal decentralization and deficits: International evidence. European Journal of Political Economy, 26(2), 155166.

Noor, M. (2012). Memahami Desentralisasi Indonesia. Yogyakarta: Interpena.

O'Boyle, E. J. (1999). Toward an improved definition of poverty. Review of Social Economy, 57(3), 281-301.

Omari, L. V., \& Muturi, W. (2016). The effect of government sectoral expenditure on poverty level in Kenya. Journal of Economics and Sustainable Development, 7(8), 219-242.

Otsuka, K., \& Kalirajan, K. (2012). Fiscal Decentralization and Development Outcomes in India: An Exploratory Analysis. 
Reid, C. A., \& Evanson, T. A. (2016). Using simulation to teach about poverty in nursing education: A review of available tools. Journal of Professional Nursing, 32(2), 130-140.

Sánchez, C. S. G., Mavrogianni, A., \& González, F. J. N. (2017). On the minimal thermal habitability conditions in lowincome dwellings in Spain for a new definition of fuel poverty. Building and Environment, 114, 344-356.

Sinnathurai, V., \& Březinová, O. (2012). Poverty Incidence and its determinants in the estate sector of Sri Lanka. Journal of Competitiveness.

Thornton, J. (2007). Fiscal decentralization and economic growth reconsidered. Journal of urban economics, 61(1), 64-70.

Todaro, M. P., \& Smith, S. C. (2006). Pembangunan ekonomi.; Edisi Kesembilan; Jilid I. Jakarta: Erlangga.
Van den Broeck, G., \& Maertens, M. (2017). Moving up or moving out? Insights into rural development and poverty reduction in Senegal. World Development, 99, 95109.

World Bank., 2006. Era Baru Pengentasan Kemiskinan di Indonesia. Jakarta: Gradasi

Xie, D., Zou, H. F., \& Davoodi, H. (1999). Fiscal decentralization and economic growth in the United States. Journal of Urban economics, 45(2), 228-239.

Yang, Z. (2016). Tax reform, fiscal decentralization, and regional economic growth: New evidence from China. Economic Modelling, 59, 520-528.

Yushkov, A. (2015). Fiscal decentralization and regional economic growth: Theory, empirics, and the Russian experience. Russian Journal of Economics, 1(4), 404418. 